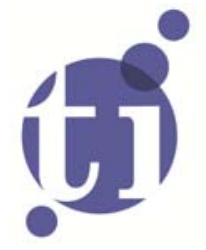

\title{
Functional and Sectoral Division of Labour within Central and Eastern European Countries: Evidence from Greenfield FDI
}

Teodora Dogarur

Martijn Burger ${ }^{2}$

Bas Karreman²,3

Frank van Oort 4

\footnotetext{
1 University of A Coruña, Spain;

2 Erasmus School of Economics, Erasmus University Rotterdam, and Tinbergen Institute, the Netherlands;

3 Erasmus Research Institute of Management, the Netherlands;

4 Utrecht University, the Netherlands.
} 
Tinbergen Institute is the graduate school and research institute in economics of Erasmus University Rotterdam, the University of Amsterdam and VU University Amsterdam.

More TI discussion papers can be downloaded at http://www.tinbergen.nl

Tinbergen Institute has two locations:

Tinbergen Institute Amsterdam

Gustav Mahlerplein 117

1082 MS Amsterdam

The Netherlands

Tel.: +31(0)205251600

Tinbergen Institute Rotterdam

Burg. Oudlaan 50

3062 PA Rotterdam

The Netherlands

Tel.: +31(0)10 4088900

Fax: $+31(0) 104089031$

Duisenberg school of finance is a collaboration of the Dutch financial sector and universities, with the ambition to support innovative research and offer top quality academic education in core areas of finance.

DSF research papers can be downloaded at: http://www.dsf.nl/

Duisenberg school of finance

Gustav Mahlerplein 117

1082 MS Amsterdam

The Netherlands

Tel.: +31(0)20 5258579 


\title{
Functional and Sectoral Division of Labour within Central and Eastern European Countries: Evidence from Greenfield FDI
}

\author{
Teodora Dogaru^ Martijn Burger ${ }^{\S} \quad$ Bas Karreman $^{*} \quad$ Frank van Oort ${ }^{\ddagger}$
}

\begin{abstract}
In this paper, we analyse the sectoral and functional division of labour in Central and Eastern European (CEE) regions within the convergence debate. By analysing the investment decisions of multinational corporations in 49 NUTS-2 regions across 6 European CEE countries (Poland, Czech Republic, Slovakia, Hungary, Romania, and Bulgaria), we show that capital city regions not only receive more greenfield FDI but also attract a larger variety of investments in terms of sectors and functions. Capital cities are more likely to host higher-end sectors and functions, which provides an explanation for the existing regional disparities within CEE countries. These results highlight the importance of functional and sectoral divisions of labour in the view of regional profiling and contribute to the recent EU Cohesion Policy debate.
\end{abstract}

Keywords: regional disparities, Central and Eastern Europe, greenfield FDI

\footnotetext{
$\wedge$ A Coruna University, Spain.

$\$$ Erasmus University Rotterdam and Tinbergen Institute, the Netherlands.

* Erasmus University Rotterdam, Tinbergen Institute, and Erasmus Research Institute of Management (ERIM), the Netherlands.

${ }^{\ddagger}$ Utrecht University, the Netherlands.
} 


\section{Introduction}

Despite regional convergence among Central and Eastern European (CEE) countries and between CEE and Western European countries, regional disparities within the CEE countries have increased considerably over the past years (e.g., Ezcurra et al., 2007; Niebuhr and Schlitte, 2009; RodriguezPose and Ezcurra, 2010; Kallioras and Petrakos, 2010; Chapman et al., 2012; Parkinson and Meegan, 2013). In the wake of EU enlargement, capital city regions started following different development trajectories and grew at a faster pace than the other regions in CEE countries (Dijkstra et al 2013). Several studies pointed to differences with respect to embeddedness in international networks and industrial restructuring as the driving forces behind regional disparities in the CEE countries (Heidenreich and Wunder, 2008; Chapman and Meliciani, 2011). Although most CEE regions experienced productivity growth in manufacturing industries, the CEE capital city regions are converging at a faster rate due to their networked, service oriented economies (Dogaru et al., 2011).

First, the CEE capital city regions are better embedded in international investment and trade networks than the other CEE cities and regions (Karreman, 2009; Bassens et al., 2010). Foreign direct investment and trade allow regions to grow faster by providing the required funding for capital projects that create jobs, enabling the transfer of new technologies, improving the productivity and the ability of firms to produce new products, expanding the scale of production by reaching new markets, and integrating into global production sharing networks. In this view, Frenken and Hoekman (2006) found that European cities that operate in international trade networks are converging faster than regions that are mostly locally oriented.

Second, there is an important role for sectoral specialisation in explaining disparities (Mora, 2005; Chapman and Meliciani, 2011). Within the CEE countries, capital city regions are characterised by large service sectors that have developed through good national and international accessibility, advanced technology, highly qualified labour and pre-existing administrative functions. Most of the other CEE regions are characterised by a low-skilled labour force and insufficient infrastructure, 
advanced technologies and regional innovation policies; they are also missing the minimum conditions to increase access to international business networks. Indeed, as Mora (2005) and Chapman and Meliciani (2011) argue, the economic profile of a region shapes its opportunities because some sectors offer better opportunities than others (e.g., the services sector has grown worldwide over the past decades, while manufacturing has declined), and the sectoral specialisations of regions do not change radically over time.

Yet, the competitive advantage of a region is not only dependent on the sectors present in the region but also on the type of activities it employs. As indicated by Chapman and Meliciani (2011), the spatial concentration of white collar labour and headquarter functions in combination with a dynamic service sector can lead to self-enforcing mechanisms of economic development. Furthermore, Duranton and Puga (2005) emphasised that the outsourcing and clustering of service functions in urban areas increases the importance of functional specialisation relative to sectoral specialisation on the regional level. Firms are more likely to locate high-end functions in metropolitan areas due to higher needs for face-to-face communication, skilled labour, and demand. At the same time, production plants and low-end service functions end up in rural areas and smaller cities due to factor cost considerations. Defever (2012) observed a similar pattern when examining the location of different business functions by multinational corporations (MNCs). ${ }^{1}$ Accordingly, it is expected that the faster growing capital city regions not only receive more FDI overall (because they are better globally embedded) and relatively more FDI in high-end sectors but also target high-end services functions such as headquarters, research and development, and sales and marketing offices. Nevertheless, the literature on regional development in the CEE countries emphasises the importance of sectoral specialisation while only limited attention has been paid to the functional division of labour among regions as a driver of regional disparities.

\footnotetext{
${ }^{1}$ Sectoral division between manufacturing and services also inadequately acknowledges the fact that service functions are increasingly carried out by firms in the manufacturing sector.
} 
The aim of our paper is to analyse to what extent regional disparities within Eastern European countries can be connected to the existence of a division of labour between the capital and the other regions. To provide a comprehensive examination of both the sectoral and functional division of labour in the CEE countries, this article focuses on the investment location decisions of MNCs in the NUTS-2 regions of CEE countries. Overall, the number of alternative locations is larger for MNCs than for domestic firms when making an investment decision. In addition, MNCs are expected to select the foreign investment locations that best fit the characteristics of the investment project and yield the largest benefits for the firm. This applies to greenfield FDI that does not face constraints from existing capital instalments or prior investments (unlike mergers and acquisitions). Hence, the location decisions of MNCs clearly reflect the particular competitive advantage of certain regions and provide a meaningful way to compare the attractiveness of different regions for particular sectors and functions. In the remainder of this article, Section 2 introduces the data while Section 3 provides an overview of the empirical results. Section 4 discusses the findings and our conclusions.

\section{Data}

In this article, we focus on greenfield FDI in 49 NUTS-2 regions in 6 CEE countries (Poland, Czech Republic, Slovakia, Hungary, Romania, and Bulgaria). Information on greenfield FDI comes from the Financial Times fDi Markets database. This project-level data was collected primarily from publicly available resources such as formal announcements by the media, financial information providers, industry organisations, and publications of companies. Overall, we have information on 7,284 investments made by 3,465 different MNCs in the 6 CEE countries between January 2003 and December 2010. ${ }^{2}$ Most greenfield investments in the CEE countries originated from within the European Union and EFTA (71\%) and North America (16\%), and these were targeted at low-tech manufacturing (21\%), medium-tech manufacturing (19\%), and commercial services (17\%). In terms of

\footnotetext{
${ }^{2}$ For 52 investments $(0.7 \%)$, we were unable to obtain the region in which the investment was made. Hence, these investments were omitted from the database. See Burger et al. (2013) for a more elaborate description of the European database on greenfield investments.
} 
functions, most investments were made in production plants (43\%), business, sales and marketing offices (23\%) as well as building and construction (11\%).

Building on Eurostat's taxonomy of metropolitan regions, the NUTS-2 regions were divided into one of the following four categories (Dijkstra, 2009; see Appendix A):

- Capital city regions: NUTS-2 regions that contain the capital city. In the 6 CEE countries, these capital city regions are also regarded as the regions that are best integrated into international markets (Fratesi, 2012).

- Regions with a second-tier city: NUTS-2 regions that include at least one second-tier city. Secondtier cities are the largest cities in the country, excluding the capital. In the CEE countries, there is a maximum of 5 second-tier cities per country.

- Regions with a smaller city: NUTS-2 regions that include at least one larger urban zone of at least 250,000 inhabitants. These larger urban zones contain major cities and are adjacent travel-towork areas.

- Non-metropolitan regions: NUTS-2 regions without an urban zone of at least 250,000 inhabitants.

Table 1: Economic development in CEE countries by region type.

\begin{tabular}{|c|c|c|c|c|c|c|}
\hline & Bulgaria & $\begin{array}{c}\text { Czech } \\
\text { Republic }\end{array}$ & Hungary & Poland & Romania & Slovakia \\
\hline \multicolumn{7}{|l|}{ GDP per Capita - PPS (2003) } \\
\hline Capital city region & 10100 & 29700 & 20590 & 15720 & 12970 & 25830 \\
\hline Regions with second-tier city & 5700 & 13600 & 8580 & 10250 & 5620 & 8610 \\
\hline Regions with smaller city & N/A & 14600 & N/A & 8442 & 6700 & N/A \\
\hline Non-metropolitan regions & 5967 & 13220 & 11742 & 8804 & 6020 & 10430 \\
\hline \multicolumn{7}{|l|}{$\begin{array}{l}\text { GDP per Capita Average } \\
\text { Annual Growth Rate (2003- } \\
\text { 2010) }\end{array}$} \\
\hline Capital city region & $8.6 \%$ & $3.2 \%$ & $3.4 \%$ & $6.6 \%$ & $10.5 \%$ & $7.3 \%$ \\
\hline Regions with second-tier city & $4.9 \%$ & $3.3 \%$ & $2.1 \%$ & $6.1 \%$ & $6.7 \%$ & $4.9 \%$ \\
\hline Regions with smaller city & N/A & $2.1 \%$ & N/A & $5.0 \%$ & $6.9 \%$ & N/A \\
\hline Non-metropolitan regions & $3.7 \%$ & $2.5 \%$ & $2.1 \%$ & $5.5 \%$ & $8.4 \%$ & $6.2 \%$ \\
\hline
\end{tabular}


Table 1 displays the large differences in level of development between the capital city regions and the other types of regions in the CEE countries; in all CEE countries, the capital city region had the highest GDP per capita in 2003. The most extreme case was Slovakia, in which the capital city region, Bratislava, had an average GDP per capita that was 2.5-3 times higher than in the other regions. The average annual growth rate of GDP per capita was also substantially higher in the capital city regions in the CEE countries (with exception of the Czech Republic). In Bulgaria, Romania, and Slovakia, the average annual growth rate (2003-2010) of the capital city regions was over two percentage points higher than the other regions. This indicates that regional disparities within the CEE countries have increased over the past decade.

Table 2: Frequency and distribution of greenfield FDI across broad economic sectors and functions by region types in CEE.

\begin{tabular}{|c|c|c|c|c|c|}
\hline & $\begin{array}{c}\text { Capital City } \\
\text { Regions }\end{array}$ & $\begin{array}{l}\text { Regions with } \\
\text { Second-Tier } \\
\text { City }\end{array}$ & $\begin{array}{l}\text { Regions } \\
\text { with } \\
\text { Smaller } \\
\text { City }\end{array}$ & $\begin{array}{l}\text { Non- } \\
\text { Metropolitan } \\
\text { Region }\end{array}$ & Total \\
\hline \multicolumn{6}{|l|}{ Sector } \\
\hline Natural Resources & $179(6)$ & $152(7)$ & $43(8)$ & $132(8)$ & $506(7)$ \\
\hline Low-Tech Manufacturing & $385(13)$ & $546(25)$ & $184(32)$ & $449(28)$ & $1564(21)$ \\
\hline Medium-Tech Manufacturing & $301(10)$ & $517(24)$ & $143(25)$ & $477(29)$ & $1438(20)$ \\
\hline High-Tech Manufacturing & $331(11)$ & $285(13)$ & $65(11)$ & $215(13)$ & $896(12)$ \\
\hline Transport Services & $182(6)$ & $130(6)$ & $30(5)$ & $59(4)$ & $401(6)$ \\
\hline Software \& ICT & $424(15)$ & $165(8)$ & $26(5)$ & $69(4)$ & $684(9)$ \\
\hline Financial Services & $327(11)$ & $100(5)$ & $10(2)$ & $74(5)$ & $511(7)$ \\
\hline Commercial Services & $786(27)$ & $281(13)$ & $69(12)$ & $148(9)$ & $1284(18)$ \\
\hline Total & $2915(100)$ & $2176(100)$ & $570(100)$ & $1623(100)$ & $7284(100)$ \\
\hline \multicolumn{6}{|l|}{ Function } \\
\hline Headquarters & $66(2)$ & $10(0)$ & $6(1)$ & $4(0)$ & $86(1)$ \\
\hline$R \& D$ & $179(6)$ & $99(5)$ & $22(4)$ & $39(2)$ & $339(5)$ \\
\hline Construction & $490(17)$ & $182(8)$ & $46(8)$ & $121(7)$ & $839(12)$ \\
\hline Extraction \& Energy & $70(2)$ & $87(4)$ & $23(4)$ & $67(4)$ & $247(3)$ \\
\hline Production Plants & 497 (17) & $1167(53)$ & $341(60)$ & $1094(67)$ & $3099(43)$ \\
\hline Logistics \& Distribution & $247(8)$ & $205(9)$ & $62(11)$ & $111(7)$ & $625(9)$ \\
\hline Business, Sales \& Marketing & $1177(40)$ & $304(14)$ & $51(9)$ & $147(9)$ & $1679(23)$ \\
\hline Support \& Servicing & $189(6)$ & $122(6)$ & $19(3)$ & $40(2)$ & $370(5)$ \\
\hline Total & $2915(100)$ & $2176(100)$ & $570(100)$ & $1623(100)$ & $7284(100)$ \\
\hline
\end{tabular}


One reason for the persistence of these disparities might be the existence of a functional and sectoral division of labour among the different types of regions. Table 2 presents the number and distribution of greenfield investments in the CEE regions by broad sector and function (see Appendix B and C for the taxonomy). Compared to the other types of regions, the capital city regions received many greenfield investments in the higher-end services sectors (software \& ICT, financial services, and commercial services) and in the headquarters, R\&D, construction and business, sales and marketing functions. At the same time, capital city regions received relatively little greenfield investment in the low- and medium-tech manufacturing sectors and production plants. This strongly suggests the existence of a functional and sectoral division of labour within the regions of the CEE countries.

\section{Empirical Model and Results}

To formally test whether the economic structure of the region types indeed differs, we complement our descriptive statistics with the estimation of discrete choice models (Wrigley, 1985; Long, 1997). When applying a discrete choice model to analyse the FDI location decisions of MNCs, it is assumed that MNCs will choose to establish a subsidiary in the location that maximises their benefit. One of the most frequently used models to analyse location decisions is the multinomial logit model (MNL). In a MNL model, the choice probabilities among a set of categorically distributed alternatives (in our case, the four types of regions) are simultaneously estimated. However, MNL assumes the independence of irrelevant alternatives (IIA), meaning that the addition or removal of a category should not affect the odds among the remaining alternatives. As a result, MNL estimation would only function well when alternatives are dissimilar (Cheng and Long, 2007). A violation of the IIA assumption results in inconsistent estimates and would require the estimation of alternative models, such as the multinomial probit (MNP) model. To test for a potential violation of the IIA assumption, we performed a Hausman-McFadden test and a Small-Hsiao test. Because the results of both the 
Hausman-McFadden and Small-Hsiao tests pointed at a confirmation of the IIA assumption, we can safely use the MNL estimation.

A common problem with the interpretation of MNL outcomes is the large number of coefficients that has to be taken into account. To facilitate interpretation, odds-ratio plots are used to display the results (Long and Freese, 2006). Figure 1 displays the odds-ratio plot based on the MNL estimates for sectors, controlling for the year in which the investment was made and the world region of origin of the investing firm (European Union/European Free Trade Association ${ }^{3}$, North America, Former USSR, Rest of Europe or Rest of World). The symbols in Figure 1 refer to Capital Regions (C), Regions with Second-Tier Cities (2), Regions with Smaller City (S), and Regions with No Metropolitan Areas (N). In the analysis, low-tech manufacturing, which has the lowest value added, functions as the reference category to which all other sectors are compared. Correspondingly, each row in the figure represents the odds of investing in a particular sector compared to investing in low-tech manufacturing for each particular type of region. The scale of the figure is set relative to capital regions because the aim of the analysis is to examine to what extent regional disparities within Eastern European countries can be connected to the existence of a division of labour between the capital and the other regions. If a symbol is positioned to the right of another symbol, then an additional investment in the particular sector is more likely to be located in that region. The distance between a pair of symbols indicates the magnitude of the effect, while a line between adjacent symbols shows that the difference between the two regions is not statistically significant (at the $5 \%$ level). Finally, it is important to take the base odds and the discrete changes in the odds into account. Note that an increase in the odds by a factor 10 has only a small impact when the current odds are 1 in 1000 and a large impact when the odds are 1 in 5 . Therefore, the size of a symbol is proportional to the magnitude of the discrete change in the odds. The vertical spacing has no meaning and is only included to improve the legibility of the figure. Several conclusions can be drawn from Figure 1. First, capital regions distinguish themselves by specialising in services sectors. Relative to the low-tech manufacturing sector,

\footnotetext{
${ }^{3}$ This includes Iceland, Liechtenstein, Norway, and Switzerland.
} 
investments in natural resources, high-tech manufacturing, transport services, software and ICT, commercial services or financial services increase the odds that an MNC will locate its affiliate in one of the capital regions and not in one of the other types of regions. In addition, relative to the lowtech manufacturing sector, investment in one of the service sectors (except for financial services) increases the odds that an MNC will invest in a region containing a second-tier city as compared to a region with a smaller city or a non-metropolitan region. These results provide some support for the observation that higher-order cities are relatively specialised in services.

Figure 1: Odds-Ratio Plot of Investing in a Particular Sector Compared to Investing in Low-Tech Manufacturing Relative to Capital Regions.

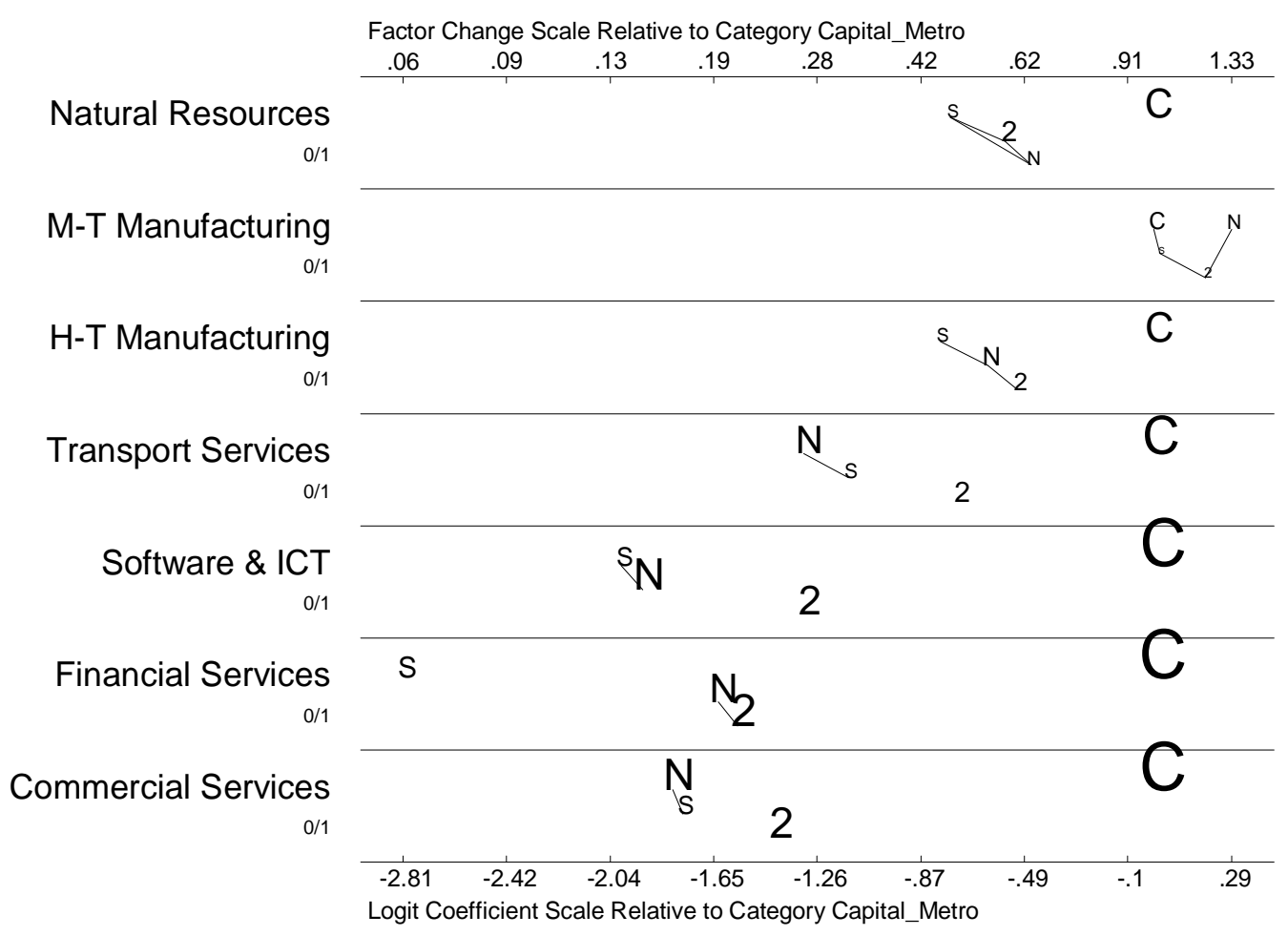

Notes: C=Capital Regions; 2=Regions with Second-Tier Cities; S=Regions with Smaller City; N=Regions with No Metropolitan Areas.

Figure 2 shows the odds-ratio plot of the MNL estimates for the functions, controlling for the year in which the investment was made and the continent from which the investments originated. The 
function with the lowest value-added production plants was chosen as the base category. Figure 2 reveals that investing in a function other than production plants increases the likelihood that an MNC will invest in a capital city region compared to one of the other types of regions. This partly provides an explanation for the persistence of regional disparities in the CEE countries. Furthermore, the figure shows less pronounced differences among the other types of regions. An MNC investing in a market-seeking function, in a business, sales and marketing office, or in a servicing and support unit instead of a production plant is more likely to locate the investment in a region with a second-tier city than in a region with a smaller city or non-metropolitan region. Unfortunately, based on our results, we cannot conclude whether the differences among the CEE regions presented are more pronounced for sectors or functions. Hence, we can only partly confirm the observation by Duranton and Puga (2005) that besides sectoral specialisation, functional specialisation also matters.

Figure 2: Odds-Ratio Plot of Investing in a Particular Sector Compared to Investing in Production Plants Relative to Capital Regions.

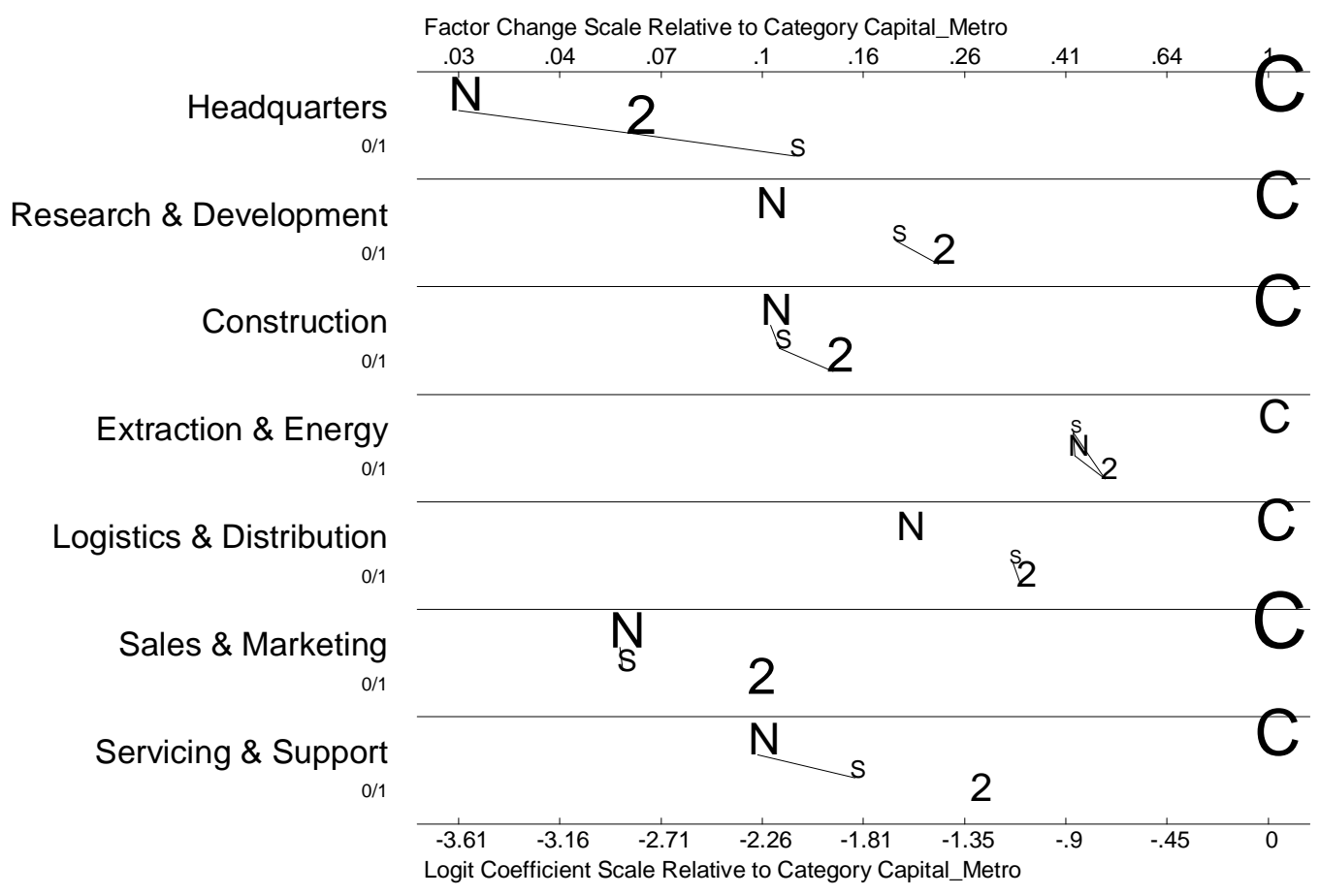

Notes: C=Capital Regions; 2=Regions with Second-Tier Cities; S=Regions with Smaller City; N=Regions with No Metropolitan Areas. 


\section{Concluding Remarks}

In this study, we examined the functional and sectoral division of labour among regions within CEE countries. The results indicate that capital city regions not only receive more greenfield FDI but also attract different types of investment in terms of sectors and functions. Because capital cities are more likely to host higher-order sectors and functions, this provides an explanation for the existing regional disparities within CEE countries. However, future research linking the sectoral and functional profile of a region to economic growth models is necessary to further test this hypothesis.

Our analysis of greenfield FDI has shown that the CEE regions have distinct competitive advantages and that some regions have better opportunities to grow than other regions. Although the convergence process of the CEE regions implies the diversification of their economies, sectoral and functional specialisations of regions do not tend to change drastically over time. Hence, this analysis is consistent with the recent EU Cohesion Policy that aims to support the economic activities in which a region has a lasting competitive advantage (Barca et al., 2012). The specificity of a region depending on its agglomerative size, sectoral, investment and knowledge network and physical accessibility suggests that place-based development strategies may enhance future development. Analyses among the regions of the same Member State depending on such peculiarities can contribute to our understanding of regional convergence. From our study, regional policies can be formulated in line with existent regional capabilities. Regional and local planning can be enhanced by better coordination of local actors, including foreign investors and local firms functionally related to these. At national level, governance can be enhanced by mapping and linking regional competitive advantages for balancing regional disparities. Increased inter- and intra-regional accessibility, openness of regional economies to trade networks, and a skilled labour force according to the regional economic specificity and development opportunities are some of the factors that contribute to the capitalization on regional competitive advantages. 


\section{References}

BARCA, F., MCCANN, P. \& RODRIGUEZ-POSE, A. (2012), The case for regional development intervention: place-based versus place-neutral approaches. Journal of Regional Science 52, pp. 134152.

BASSENS, D., DERUDDER, B., TAYLOR, P.J., NI, P., HOYLER, M. \& WITLOX, F. (2010), World city network integration in the Eurasian realm. Eurasian Geography and Economics 51, pp. 385-401.

BURGER, M.J., VAN DER KNAAP, G.A. \& WALL, R.S. (2013), Revealed competition for greenfield investments between European regions. Journal of Economic Geography 13, pp. 619-648.

CHAPMAN, S.A. \& MELICIANI, V. (2012), Income disparities in the enlarged EU: socio-economic, specialisation and geographical clusters. Tijdschrift voor Economische en Sociale Geografie 103, pp. 293-311.

CHAPMAN, S.A., COSCI, S. \& MIRRA, L. (2012) Income dynamics in an enlarged Europe: the role of capital regions. Annals of Regional Science

CHENG, S. \& LONG, J.S. (2007), Testing for the IIA in the multinomial logit model. Sociological Methods \& Research 35, pp. 583-600.

DEFEVER, F. (2012), The spatial organization of multinational firms. Canadian Journal of Economics 45, pp. 672-697.

DIJKSTRA, L. (2009), Metropolitan regions in Europe. Regional Focus n ${ }^{0} 1 / 2009$.

DIJKSTRA, L., GARCILAZO, E. \& MCCANN, P. (2013), The economic performance of European cities and city regions: myths and realities. European Planning Studies 21, pp. 334-354.

DOGARU, T., VAN OORT, F. \& THISSEN, M. (2011), Agglomeration economies in European regions: perspective for Objective 1 regions. Tijdschrift voor Economische en Sociale Geografie 102, pp. 486494.

DURANTON, G. \& PUGA, D. (2005), From sectoral to functional urban specialization. Journal of Urban Economics 57, pp. 343-370.

EZCURRA, R., PASCUAL, P. \& RAPÚN, M. (2007), The dynamics of regional disparities in Central and Eastern Europe during transition. European Planning Studies 15, pp. 1397-1421.

FRATESI, U. (2012), A globalization-based taxonomy of European regions. Regional Science Policy \& Practice 4, pp. 1-23.

FRENKEN, K. \& HOEKMAN, J. (2006), Convergence in an enlarged Europe: the role of network cities. Tijdschrift voor Economische en Sociale Geografie 97, pp. 321-326.

HEIDENREICH, M. \& WUNDER, C. (2008), Patterns of regional inequality in the enlarged Europe. European Sociological Review 24, pp. 19-36.

KALLIORAS, D. \& PETRAKOS, G. (2010), Industrial growth, economic integration and structural change: evidence from the EU new member states regions. Annals of Regional Science 45, pp. 667680 . 
KARREMAN, B. (2009), Financial geographies and emerging markets in Europe. Tijdschrift voor Economische en Sociale Geografie 100, pp. 260-266.

LONG, J. S. (1997), Regression Models for Categorical and Limited Dependent Variables. Thousand Oaks: Sage.

LONG, J.S. \& FREESE, J. (2006), Regression Models for Categorical Dependent Variables using Stata. College Station: Stata Press.

MORA, T., VAYA, E. \& SURINACH, J. (2005), Specialisation and growth: the detection of European regional convergence clubs. Economics Letters 86, pp. 181-185.

NIEBUHR, A. \& SCHLITTE, F. (2009), EU enlargement and convergence: does market access matter? Eastern European Economics 47, pp. 28-56.

PARKINSON, M. \& MEEGAN, R. (2013), European cities in an age of austerity: why invest beyond the capitals? Working paper, IRPET Seminar, Florence.

RODRIGUEZ-POSE, A. (1998), The Dynamics of Regional Growth in Europe. Social and Political Factors. Oxford: Clarendon Press.

RODRIGUEZ-POSE, A. \& EZCURRA, R. (2010), Does decentralization matter for regional disparities? A cross-country analysis. Journal of Economic Geography 10, pp. 619-644.

WRIGLEY, N. (1985), Categorical Data Analysis for Geographers and Environmental Scientists. London: Longman Group. 
Appendix A: Taxonomy of Regions

\begin{tabular}{|c|c|c|c|}
\hline NUTS-code & Region Type & NUTS-code & Region Type \\
\hline BG31 & Non-Metropolitan Region & PL31 & Region with Smaller City \\
\hline BG32 & Non-Metropolitan Region & PL32 & Region with Smaller City \\
\hline BG33 & Region with Second-Tier City & PL33 & Region with Smaller City \\
\hline BG34 & Non-Metropolitan Region & PL34 & Region with Smaller City \\
\hline BG41 & Capital City Region & PL41 & Region with Second-Tier City \\
\hline BG42 & Region with Second-Tier City & PL42 & Region with Smaller City \\
\hline CZO1 & Capital City Region & PL43 & Non-Metropolitan Region \\
\hline CZO2* & Capital City Region & PL51 & Region with Second-Tier City \\
\hline CZO3 & Region with Smaller City & PL52 & Region with Smaller City \\
\hline CZO4 & Non-Metropolitan Region & PL61 & Region with Smaller City \\
\hline CZO5 & Non-Metropolitan Region & PL62 & Region with Smaller City \\
\hline CZO6 & Region with Second-Tier City & PL63 & Region with Second-Tier City \\
\hline CZO7 & Non-Metropolitan Region & R011 & Region with Second-Tier City \\
\hline CZO8 & Region with Second-Tier City & R012 & Region with Smaller City \\
\hline HU10 & Capital City Region & $\mathrm{RO} 21$ & Region with Second-Tier City \\
\hline HU21 & Non-Metropolitan Region & $\mathrm{RO} 22$ & Region with Second-Tier City \\
\hline HU22 & Non-Metropolitan Region & R031 & Non-Metropolitan Region \\
\hline HU23 & Non-Metropolitan Region & RO32 & Capital City Region \\
\hline HU31 & Region with Second-Tier City & R041 & Region with Second-Tier City \\
\hline HU32 & Region with Second-Tier City & RO42 & Non-Metropolitan Region \\
\hline HU33 & Non-Metropolitan Region & SK01 & Capital City Region \\
\hline PL11 & Region with Second-Tier City & SK02 & Non-Metropolitan Region \\
\hline PL12 & Capital City Region & SK03 & Non-Metropolitan Region \\
\hline PL21 & Region with Second-Tier City & SK04 & Region with Second-Tier City \\
\hline PL22 & Region with Second-Tier City & & \\
\hline
\end{tabular}


Appendix B: Taxonomy of Investments by Broad Sectors

\begin{tabular}{|c|c|}
\hline Category & Sectors \\
\hline Natural Resources & $\begin{array}{l}\text { Alternative/Renewable Energy } \\
\text { Chemicals } \\
\text { Coal, Oil \& Natural Gas } \\
\text { Minerals }\end{array}$ \\
\hline Low-Tech Manufacturing & $\begin{array}{l}\text { Beverages } \\
\text { Ceramics \& Glass } \\
\text { Consumer Products } \\
\text { Food \& Tobacco } \\
\text { Metals } \\
\text { Paper, Printing \& Packaging } \\
\text { Plastics } \\
\text { Rubber } \\
\text { Textiles } \\
\text { Wood Products }\end{array}$ \\
\hline Medium-Tech Manufacturing & $\begin{array}{l}\text { Automotive Components } \\
\text { Automotive OEM } \\
\text { Building \& Construction Materials } \\
\text { Engines \& Turbines } \\
\text { Industrial Machinery } \\
\text { Non-Automotive Transport OEM }\end{array}$ \\
\hline High-Tech Manufacturing & $\begin{array}{l}\text { Aerospace } \\
\text { Biotechnology } \\
\text { Business Machines \& Equipment } \\
\text { Consumer Electronics } \\
\text { Electronics Components } \\
\text { Medical Devices } \\
\text { Pharmaceuticals } \\
\text { Semiconductors }\end{array}$ \\
\hline Transport Services & $\begin{array}{l}\text { Transportation } \\
\text { Warehousing \& Storage }\end{array}$ \\
\hline Software \& ICT & $\begin{array}{l}\text { Communications } \\
\text { Software \& IT Services } \\
\text { Space \& Defense }\end{array}$ \\
\hline Financial Services & Financial Services \\
\hline Commercial Services & $\begin{array}{l}\text { Business Services } \\
\text { Real Estate } \\
\text { Healthcare } \\
\text { Hotels \& Tourism } \\
\text { Leisure \& Entertainment }\end{array}$ \\
\hline
\end{tabular}


Appendix C: Taxonomy of Investments by Broad Functions

\begin{tabular}{|l|l|}
\hline Category & Functions \\
\hline Headquarters & Headquarters \\
\hline R\&D & $\begin{array}{l}\text { Design, Development, and Testing } \\
\text { Education and Training } \\
\text { Research and Development }\end{array}$ \\
\hline Construction & $\begin{array}{l}\text { Construction } \\
\text { ICT and Internet Infrastructure }\end{array}$ \\
\hline Extraction \& Energy & Extraction \\
& Energy \\
\hline Production Plants & Manufacturing \\
\hline Business, Sales \& Marketing & Business Services \\
& Sales, Marketing, and Support \\
\hline Support \& Servicing & Customer Contact Centres \\
& Maintenance \& Servicing \\
& Shared Service Centres \\
& Technical Support Centres \\
\hline Logistics \& Distribution & Logistics, Distribution and Transportation \\
& Retail \\
\hline
\end{tabular}

